\title{
Antecedents of Organizational Citizenship Behavior among Academic Staff in Universities in Uganda: A Conceptual Paper
}

\author{
J. Kabasiita ${ }^{1}$, F. E. K. Bakkabulindi ${ }^{2}$, D. Onen ${ }^{2}$ \\ ${ }^{I}$ School of Education, Mountains of the Moon University; \\ ${ }^{2}$ East African School of Higher Education Studies and Development, College of Education and External Studies, Makerere \\ University
}

\begin{abstract}
An employee who displays organizational citizenship behavior $(\mathrm{OCB})$ is likely to have high job performance because he/she requires minimal monitoring from their supervisors. It is therefore important to isolate antecedents of OCB. In this study we use Podsakoff, MacKenzie, Paine and Bachrach's (2000) model, of $\mathrm{OCB}$ to isolate antecedents of $\mathrm{OCB}$ among academic staff in universities in Uganda. According the model, we postulate that OCB is a function of employee characteristics, task characteristics, organizational characteristics, and leadership behavior. In this paper, we give the background of the study, the problem; study objectives and significance. We also review literature related to the objectives and draw hypotheses thereof. Using a positivism approach, we suggest the methodology we shall use to test hypotheses.
\end{abstract}

Key words: Academic staff, Antecedents, OCB, Positivism.

\section{BACKGROUND}

\subsection{Historical Perspective.}

$\mathrm{T}$ The concept of OCB was first formally articulated by Chester Barnard (Barnard, 1938). Barnard proposed the term "willingness to cooperate" defining cooperation as indisputable restraint of oneself, voluntary service for no reward and subjection of one's own personal interests for the betterment of the organization. From this, one notes that integral to Barnard's view of willingness to cooperate is the conception of an individual exercising his/ her freewill while participating in a formal system of cooperation. Katz (1964) building on from Barnard described this willingness to cooperate kind of behavior as "innovative and spontaneous behavior". From the three fundamental types of behavior essential for functioning organization that Katz had suggested, one of the was that an employee should engage in innovative and spontaneous behaviors that goes beyond task prescriptions. Concerning this category, Katz pointed out that an organization which depended solely upon its blue prints of prescribed behavior was a very fragile social system. They contended that every institution depended daily on a myriad of cooperation, helpfulness, suggestions, gestures of goodwill, altruism/ humility, and other instances of what we might call citizenship behavior.
In 1983, Bateman and Organ coined the now popular term organizational citizenship behavior (OCB). Bateman and Organ (1983) defined OCB as organizationally beneficial behaviors and gestures by an employee that could neither be obligatory on the basis of formal role requirement nor elicited by contractual guarantee of remuneration. They posited that OCB consisted of informal assistance an employee could choose to volunteer or withhold without regard to considerations of sanction or official incentives. Also related to OCB, Brief and Motowidlo (1986) presented a construct they named as "pro-social organizational behavior" (POB) which they defined as positive societal acts that are carried out by an employee to generate and uphold the wellbeing and integrity of others. They emphasized that pro-social behaviors were those behaviors which were performed by an employee in an organization, directed toward an individual, group or organization.

A wide range of empirical studies have been done on antecedents of OCB. As justification, we highlight literature reviews (e.g. Chiaburu, Oh, Berry \& Gardner, 2011; Nohe \& Hertel, 2017) on antecedents of OCB. For example, Chiaburu et al. (2011) having reviewed 87 studies, they noted that many studies had only used a general measure of OCB without measuring its dimensions; some studies had methodological gaps where the cause and effect of the variables they had studied could not be inferred. Nohe and Hartel (2017) reviewed 761 studies and reported that, many studies did not differentiate between the different forms of both OCB and transformational leadership behaviors. Had the two variables been operationalized and measured differently, different results would have come out. In this study, we shall deal with antecedents of OCB in universities in Uganda.

1.2. Theoretical Perspective. Our study will be guided by Podsakoff, MacKenzie, Paine and Bachrach's (2000) model, which resulted from their critical review of the theoretical and empirical literature on OCB. They suggested a model on antecedents of OCB. The model has four constructs, namely employee characteristics, task characteristics, organizational characteristics, and leadership behavior. They suggested that employee characteristics, task characteristics, organizational characteristics, and leadership behavior are positive 
antecedents, that is, they have a positive correlation with one's level of OCB. In other words, according to Podsakoff et al. (2000), if any of these four antecedents increases, there will be greater levels of OCB and vice versa.

1.3 Conceptual Perspective. The main variable in this study is OCB which is the dependent variable. OCB refers to organizationally beneficial behaviors and gestures by an employee that could neither be obligatory on the basis of formal role requirement nor elicited by contractual guarantee of remuneration (Bateman \& Organ, 1983). Regarding the operational definition of OCB, the study will use the scale that was developed by Podsakoff, Mackenzie, Moorman and Fetter (1990) to define OCB as altruism, courtesy, sportsmanship, conscientiousness and civic virtue. Podsakoff et al. (1990) define altruism as behaviors that consist of those voluntary actions that help another person with work related problems while conscientiousness as behavior which indicates that an employee is in acceptance and in adherence to the rules, regulations and procedures of an organization. Podsakoff et al. (1990) defined sportsmanship as willingness on the part of an employee to tolerate less than ideal circumstances without complaining about trivial matters. They also explained that courtesy means consulting with others before taking action while they defined civic virtue as keeping up with issues that affect the organization.

Our proposed study has four independent variables as antecedents of OCB namely; employee characteristics, task characteristics, organizational characteristics, and leadership behaviors. An antecedent is a factor that leads to the occurrence of something. Employee characteristics are enduring patterns of thought and behaviors that are not likely to change over time and explain an employee's behavior across different situations (Matin, Jandaghi, \& Ahmadi, 2010). In this study, basing on Podasakoff et al.'s (2000) model, employee characteristics refer to demographic variables; job satisfaction; perceived organizational justice; organizational commitment; and self-efficacy. In particular, Macdonald (1997) defined job satisfaction as an employee's general expression of positive attitudes towards his/her job. In our study, job satisfaction will be operationalized using the instrument by Macdonald (1997). With regard to perceived organizational justice, Colquitt (2001) defines it as the perception of an employee on the fairness of treatment received from an organization and the employee's behavioral reaction to such perceptions. Colquitt categorized organizational justice as distributive justice; procedural justice; interactional justice; informational justice. Colquitt explained that distributive justice is fostered where outcomes are consistent with explicit norms for allocation such as equity or equality while defines procedural justice as processes that lead to decision making outcomes. In addition, Colquitt explains that interactional justice is the interpersonal treatment an employee receives as procedures are being enacted while informational justice focuses on the extent to which an employee in an organization receives explanations on information conveyed regarding why procedures are used or why certain decisions are made. Organizational justice will be operationalized using Colquitt's (2001) tool.

Another operational concept under employee characteristics is organizational commitment (OC). Meyer, Allen \& Smith (1993) define OC as an intention to persist in a course of action. Meyer et al. further asserted that a committed employee will work hard and likely to go an extra mile to achieve organizational objectives. We shall use Meyer et al.'s tool to measure organizational commitment. Selfefficacy as an operational concept of individual characteristics is defined as beliefs in one's capabilities to organize and execute the courses of action required to produce given attainments (Bandura, 2009). To measure self-efficacy, Schwarzer and Jerusalem's (1995) tool will be used.

Another independent variable in this study is task characteristics. According to Johari, Mit, and Yahya (2009), task characteristics are concerned with how a task is performed and the range and nature of tasks associated with a particular job. They posited that there are five different aspects of a task, namely skill variety, task identity, task significance, autonomy and feedback. Johari et al. (2009) defined skill variety as the degree to which a task requires a wide range of activities in carrying out work and involves the use of a number of different skills and talents of the employee. Task identity according to Johari et al. (2009) is the feeling that the task is meaningful and worthwhile thus motivating the employee to work. They also defined task significance as the degree to which a job has a substantial impact on the lives or work of other people whether in the immediate organization or in the external environment. Johari et al. (2009) further explained that autonomy is the degree to which a task provides freedom, independence and discretion to the employees in scheduling his or her work and in determining the procedures to be used in carrying it out. They theorized that when an employee is free within the organization chances are high that this person will reciprocate working more than what is defined on the task. They defined feedback as the degree to which carrying out the work activities required by the job results in the employee obtaining information about the effectiveness of his or her performance. In this study, task characteristics will be measured using Johari et al.'s (2009) tool.

Organizational characteristics are another independent variable which is an antecedent of OCB. According to Matin et al. (2010) organizational characteristics are qualities that an organization has that affect an employee. In our study, organizational characteristics will be operationalized as organizational structure; advisory support; group cohesiveness; and organizational support. Johari, Yahya, and Omar (2011) define organizational structure as practices undertaken in an organization with regard to policies, procedures and rules. Johari et al.'s tool will be used for the measurement of organizational structure. Yoon and Lim (1999) define advisory support (AS) as support offered to 
an employee by his/ her immediate supervisor. To measure AS, the proposed study will use Yoon and Lim's tool. Group cohesiveness is defined by some authors (e.g. Kiesewetter \& Fischer, 2015) as the willful contribution of personal effort to the completion of interdependent tasks. To measure group cohesiveness this study will use Kiesewetter and Fischer's (2015) tool. Eisenberger, Armeli, Rexwinkel, Lynch, and Rhoades (2001) define organizational support (OS) as a feeling that an organization cares for an employee. In this study, we shall measure OS using Eisenberger et al.'s tool.

Another independent variable in this study is leadership behaviors. Yukl (2010) defines leadership as "the process of influencing others to understand and agree about what needs to be done and how to do it, and the process of facilitating individual and collective efforts to accomplish shared objectives" (p. 8). In accordance to Podasakoff et al.'s (2000) model, leadership behaviors are transformational and transactional. Podsakoff et al. (1990) defined transformational behavior as a type of behavior that raises followers' awareness of the importance and value of designated outcomes and ways of reaching the outcomes. They mentioned that a leader with transformational behavior move followers to adopt a moral purpose, transcend self-interest for the sake of collective interest, and strive for higher order needs. Podsakoff et al. mentioned that transformational behaviors comprise of articulating a vision, providing an appropriate model, fostering the acceptance of group goals, high performance expectations, and intellectual stimulation. Podsakoff et al. (1990) also defined transactional leadership as an exchange process between leaders and followers for the sake of their own interest, with leaders providing follower's praise, rewards, and resources or the avoidance of disciplinary action in turn for followers' acceptance and compliance with leaders' expectations. We adopted, Ismail, Mohamad, Mohamed, Rafiuddin and Zhen's (2010) tool to measure leadership behaviors.

\section{STATEMENT OF THE PROBLEM}

The importance of OCB is well captured by authors. For example Bateman and Organ (1983) explained that an employee who displays OCB is likely to have high job performance because he/ she requires minimal monitoring from their supervisors. Borman (2004) contended that OCB of an employee promotes productivity in an organization. Organ and Konovsky (1989) noted that an employee who demonstrates OCB reduces on an organization's expenditure on the account of the extra work done and yet is not paid for by the organization such as a university. This implies that lack of OCB in any organization will result in loss of organizational values and low employee productivity. Although several studies have been done on concept of OCB, few studies have attempted to explain what causes OCB. In addition, majority of the studies have been conducted in the developed world not in developing nations Uganda inclusive.
Those that have tried to explain its occurrence have not entirely tested all the constructs as suggested by Podsakoff et al.'s (2000) model. It is as a result of this background that basing on Podsakoff et al.'s (2000) model, out study will appraise whether employee characteristics; task characteristics; organizational characteristics; and leadership behaviors are antecedents of OCB in universities in Uganda.

\section{OBJECTIVES AND SIGNIFICANCE}

The general objective of this study is to test the applicability of Podsakoff et al.'s (2000) model in the context of universities in Uganda. Hence, the following are the specific objectives:

1) To analyze whether employee characteristics are antecedents of OCB.

2) To examine whether task characteristics are antecedents of OCB.

3) To examine whether organizational characteristics are antecedents of OCB.

4) To assess whether leadership behaviors are antecedents of OCB.

Significantly, the findings from the study will help researchers to understand the applicability of Podsakoff et al.'s (2000) model; and thus open up areas for further research with regard to OCB. The study will help universities to understand antecedents of OCB in universities. This will help universities to put emphasis on those antecedents that that enhance OCB.

\section{CONCEPTUAL FRAMEWORK}

Figure 1 shows a conceptual framework on OCB and its antecedents.

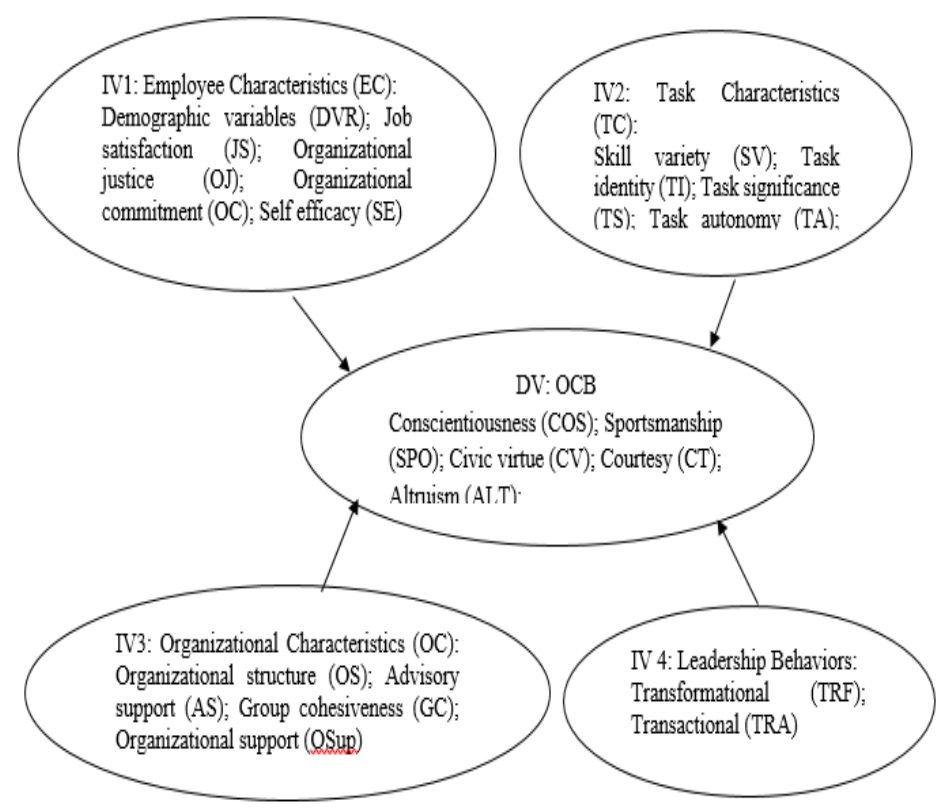

Figure 1: Conceptual Framework relating OCB and employee characteristics, task characteristics, organizational characteristics, and leadership behavior as its antecedents 
In this study, we operationalize our dependent variable (OCB) according to Podsakoff et al. (1990) as conscientiousness (COS); sportsmanship (SPO); civic virtue (CV); courtesy (CT); and altruism (ALT). The first independent variable (Employee Characteristics) is operationalized as job satisfaction (JS) (Macdonald, 1997); organizational justice (OJ) (Colquitt, 2001); organizational commitment (OC) (Meyer et al., 1993); self-efficacy (SE) (Schwarzer \& Jerusalem, 1995). The second independent variable (Task Characteristics) is operationalized as according to Johari et al. (2009) as skill variety (SV); task identity (TI); task significance (TS); task autonomy (TA); and feedback (FB). The third independent variable (Organizational Characteristics) is operationalized organizational structure (OS) (Johari, et al., 2011); advisory support (AS) (Yoon \& Lim, 1999); group cohesiveness (GC) (Kiesewetter \& Fischer, 2015); and organizational support (OSup) (Eisenberger, et al., 2001). The fourth independent variable (Leadership Behaviors) is operationalized according to Ismail et al. (2010) as transformational (TRF); and transactional (TRA).

\section{RELATED LITERATURE}

5.1 Literature Reviews on Antecedents of $O C B$. A number of studies have been done on the antecedents of OCB. Therefore, in this section as evidence we review literature review papers that have been conducted on antecedents of OCB. For example, Chiaburu et al. (2011) carried out a meta-analysis examining the relationship between five-factor model (FFM) of personality traits and OCB. Their study involved a metaanalytic test based on 87 statistically independent samples where Schmidt-Hunter random effects meta-analysis method was used to synthesize effect size estimates. They carried out literature searches whereby "articles were identified through multiple databases and multiple methods including electronic searches of the PshycINFO (1887-2010), Management and Organization Studies (1947-2010), PsycARTICLES, PsycBOOKS (1806-2010), Psychology (1969-2010), and ProQuest dissertations and theses databases" (p. 1143). Chiaburu et al. also did a manual electronic search of reference lists of key articles and prior meta-analyses on FFM of traits and OCB. They hence found that "emotional stability, extraversion, and openness had incremental validity for citizenship over and above conscientiousness and agreeableness" (p. 1150). Finally, they compared the effect sizes obtained in the meta-analysis with the comparable effect sizes predicting task performance from previous metaanalyses. As a result, Chiaburu et al. (2011) found out that "conscientiousness, emotional stability, and extraversion had similar magnitudes of relationships with OCB" (p. 1152). However, Chiaburu et al. pointed out, they noted that many studies had only used a general measure of OCB without measuring its dimensions. Also, some studies had methodological gaps where the cause and effect of the variables they had studied could not be inferred.

Eatough, Chang, Miloslavic and Johnson (2011) carried out a "quantitative review on the relationship between role stressors (i.e., role ambiguity, role conflict \& role overload) and OCB" (p. 619). To get literature, they used five databases namely, PsycINFO, ABI/Inform, Medline, ERIC, and Google Scholar to search for literature. Eatough et al. also compared their reference lists with reference lists of existing reviews of OCB and role stressors; and contacted researchers on the same subject. Eatough et al. included only empirical studies that investigated relationships between OCB and at least one role stressor; correlation coefficients were collected as effect sizes; and those that examined correlations between OCB and work demands, time pressure and workload as effect sizes for the role overload-OCB relationship. They hence reviewed 42 studies. They found out that role stressors had had a negative significant relationship with OCB. They however reported that various studies they had reviewed had limitations. For example, the number of empirical studies examining relationship between role stressors and OCB was relatively small.

Petrella (2013) conducted a meta-analytic study to explore whether different referents of trust were correlated with OCB. Petrella searched for articles using PsychInfo, JSTOR, Business Source Premiere and Google Scholar databases. He also did back-searching of the articles he had located during the database search. Petrella included studies that had not been analyzed by the Dirks and Ferrin (2002); those that had reported correlation coefficients; those that had included the list of referents of trust; and had made OCB as a dependent variable. Petrella thus reviewed 23 sample studies. He hence reported that referents of trust had been significantly related to OCB. However, Petrella reported a gap from the reviewed studies that majority of the studies had measured interpersonal trust but not overall trust.

Nohe and Hertel (2017) examined "four potential mediators of the positive relationship between transformational leadership behaviors and OCB" (p. 9). According to them, the potential mediators were "job satisfaction, affective organizational commitment; trust in the leader; and leader member exchange" (p. 9). They did a literature search using PsycInfo and Google scholar. They also searched from journals such as Journal of Management, Journal of Applied Psychology, The Leadership Quarterly, and Personnel Psychology. When they tested the four mediators individually, their results showed that each of them mediated the association between transformational leadership behaviors and OCB. However, when tested them concurrently, they found that LMX was the stronger mediator compared to job satisfaction and organizational commitment" (p. 9). However, Nohe and Hertel reported a gap arising the studies they had reviewed. That is "many studies did not differentiate between the different forms of OCB" (p. 10). This implies that if studies had differentiated the different forms of OCB, different foci of OCB would have produced different results from what was reported by the studies reviewed. 
5.2 Hypotheses. As we have noted in subsection 5.1, literature reviews have pointed out gaps on previous studies. In this proposed study, such gaps will be bridged by testing Podsakoff et al.'s (2000) model on academic staff in universities in Uganda. In this regard, four hypotheses will guide the study, namely;

1. Employee characteristics are positive antecedents of OCB.

2. Task characteristics are positive antecedents of OCB.

3. Organizational characteristics are positive antecedents of OCB.

4. Leadership behaviors are positive antecedents of OCB.

\section{METHODOLOGY}

6.1 Research Paradigm and Design. This study will take a positivist approach. In particul'ar, it will apply a co-relational and cross-sectional survey design. It will be co-relational in a sense that it will ascertain how each antecedent (i.e. individual, task, organization characteristics and leadership behaviors) suggested by Podsakoff et al. (2000) will be related to organizational citizenship behavior (OCB). The study will be cross-sectional because data will be collected from respondents once to reduce costs and time.

6.2 Sample. This study will have one category of respondents, namely academic staff in universities in Uganda. The choice of the universities has been based on their ownership (i.e. public or private) and age. Makerere University (Mak) will represent public old universities; Mbarara University of Science and Technology (MUST) will be a sample from public new university. Uganda Martyrs University (UMU), Nkozi and Mountains of the Moon (MMU) will respectively represent private old and private new u. The numbers of teaching staff in the respective universities are Mak (1650), MUST (200), UMU (50) and MMU (70).

6.3 Data Collection Instrument. In this study, we shall use a self-administered questionnaire (SAQ) to collect data. We developed the SAQ by using ready-made instruments by other| scholars as in Table 1. Our application of ready-made instruments is because their validities and reliabilities have been tested and used in various scholarly work.

Table 1: Variables in the Instrument, their Constructs, Sources and Reliabilities

\begin{tabular}{|c|c|c|}
\hline Variable & Construct & $\begin{array}{l}\text { Sources of Instrument, Number of Items in it } \\
\text { and their Reliability. }\end{array}$ \\
\hline $\mathrm{OCB}(\mathrm{DV})$ & $\begin{array}{c}\text { Altruism (ALT; Courtesy (CT); Sportsmanship } \\
\text { (SPO); Conscientiousness (COS); Civic virtue } \\
(\mathrm{CV})\end{array}$ & Podsakoff et al. (1990): 24 items, $\alpha=0.94$ \\
\hline \multirow{4}{*}{$\begin{array}{c}\text { Employee } \\
\text { characteristics (IV1) }\end{array}$} & Job satisfaction (JS) & Macdonald (1997): 10 items, $\alpha=0.77$ \\
\hline & $\begin{array}{c}\text { Organizational justice (OJ): Procedural justice } \\
\text { (PJ); Distributive justice (DJ); Interpersonal } \\
\text { justice (IJ); Informational justice (IJ) }\end{array}$ & $\begin{array}{c}\text { Colquitt (2001): (PJ } 7 \text { items } \alpha=0.78 ; \text { DJ } 4 \\
\text { items, } \alpha=0.92 ; \text { IJ } 4 \text { items, } \alpha=0.79 ; \text { IJ } 5 \\
\text { items, } \alpha=7.9)\end{array}$ \\
\hline & $\begin{array}{l}\text { Organizational commitment: (affective }(\mathrm{AC}) \text {; } \\
\text { continuance }(\mathrm{CC}) \text {; normative }(\mathrm{NC})\end{array}$ & $\begin{array}{l}\text { Meyer et al. (1993): } 18 \text { items, (AC } 6 \text { items, } \alpha \\
=0.87 \text {; CC } 6 \text { items, } \alpha=0.75 ; \text { NC } 6 \text { items, } \alpha \\
=0.79)\end{array}$ \\
\hline & Self-Efficacy (SE) & $\begin{array}{l}\text { Schwarzer and Jerusalem (1995): } 10 \text { items, } \alpha \\
=0.79\end{array}$ \\
\hline $\begin{array}{l}\text { Task characteristics } \\
\text { (IV2) }\end{array}$ & $\begin{array}{c}\text { Skill variety (SV); Task identity (TI); Task } \\
\text { significance (TS); Task Autonomy (TA); } \\
\text { Feedback (FB) }\end{array}$ & $\begin{array}{c}\text { Johari et al. (2009): } 11 \text { items in total, (SV } 2 \\
\text { items, } \alpha=0.61) \text {; TI ( } 2 \text { items, } \alpha=0.63) \text {; TS } \\
\text { (2 items, } \alpha=0.61) \text {; AU ( } 2 \text { items, } \alpha=0.82) \text {; } \\
\text { TF ( } 3 \text { items, } \alpha=0.79)\end{array}$ \\
\hline \multirow{4}{*}{$\begin{array}{c}\text { Organizational } \\
\text { characteristics (IV3) }\end{array}$} & Organizational structure (OS) & Johari, et al. (2011): 10 items, $\alpha=0.76$ \\
\hline & Advisory support (AS) & Yoon and Lim (1999): 3 items, $\alpha=0.70$ \\
\hline & Group cohesiveness (GC) & $\begin{array}{l}\text { Kiesewetter and Fischer (2015): } 17 \text { items, } \alpha= \\
0.78\end{array}$ \\
\hline & Organizational support (Osup) & Eisenberger, et al. (2001): 10 items, $\alpha=0.90$ \\
\hline $\begin{array}{l}\text { Leadership behaviors } \\
\text { (IV4) }\end{array}$ & $\begin{array}{c}\text { Transformational (TRF) } \\
\text { Transactional (TRA) } \\
\end{array}$ & $\begin{array}{c}\text { Ismail et al. (2010): TRF, } 10 \text { items, } \alpha=0.95 \text {; } \\
\text { TRA, } 5 \text { items, } \alpha=0.84\end{array}$ \\
\hline
\end{tabular}

6.3 Data Management. Four multiple linear regression models (MLRMs) will be used to test the hypotheses in the study. The first MLRM will regress the main variable OCB on the first independent variable (IV1), namely employee characteristics. The respective three other MLRMs will regress OCB on IV2 (task characteristics); IV3 (organizational characteristics); and IV4 (leadership behavior).

\section{SUMMARY}

In this article, we tried to make a case on OCB by highlighting how it has evolved over time and its importance. Through literature as well, we have isolated antecedents of OCB by using Podsakoff et al.'s (2000) model. As a result of the 
model, we developed objectives, hypotheses and suggested methodology on how the objectives would be achieved.

\section{REFERENCES}

[1] Bandura, A. (2009). Cultivate self-efficacy for personal and organizational effectiveness. In E. A. Locke (Ed.), Handbook of principles of organization behavior $\left(2^{\text {nd }} \mathrm{ed}\right)$, pp. 179-200. New York, NY: Wiley. Retrieved from www.scholarcommons.usf.edu/psy www.uky.edu

[2] Barnard, C. I. (1938). The functions of the executive. New York, NY: Oxford University Press. Retrieved from www. jstor.org

[3] Bateman, S. T., \& Organ, W.D. (1983). Job satisfaction and the good soldier: The relationship between affect and employee citizenship. Academy of Management Journal, 26(4), 587-595. doi: $10.5465 / 255908$

[4] Borman, W. C. (2004). The concept of organizational citizenship. American Psychological Society, 13(13), 238-241. Retrieved from www.scholarcommons.usf.edu/psy

[5] Borman, W. C., Penner, L. A., Allen, T. D., \& Motowildo, S. J. (2001). Personality predictors of citizenship performance. International Journal of Selection and Assessment, 9(1/2), 52-69. Retrieved from www.reseachgate.net

[6] Burns, T., \& Carpenter, J. (2008). Organizational citizenship behaviour and student achievement. Journal of Cross-Disciplinary Perspectives in Education, 1(1), 51-58. Retrieved from www.people.wm.edu

[7] Chiaburu, D. S., Oh, I., Berry, C. M., Li, N., \& Gardner, R. G. (2011). The five-factor model of personality traits and organizational citizenship behaviors: A meta-analysis. Journal of Applied Psychology, 96(6), 1140-1166. doi: 10.1037/a0024004

[8] Colquitt, J. A. (2001). Dimensionality of organizational justice: A construct validity of a measure. Journal of Applied Psychology, 86(3), 386-400. doi: 10.1037//0021-9010.86.3.386

[9] Dirks, K. T., \& Ferrin, D.L. (2002). Trust in leadership: Metaanalytic findings and implications for research and practice. Journal of Applied Psychology, 87(4), 611-628. Retrieved from www.psycnet.apa.org

[10] Eatough, M. E., Chang, C., Miloslavic, S. A, \& Johnson, R. E. (2011). Relationship of role stressors with organizational citizenship behavior: A meta-analysis. Journal of Applied Psychology, 96(3), 619-632. doi: 10.1037/a0021887

[11] Eisenberger, R., Armeli, S., Rexwinkel, B., Lynch, P. D., \& Rhoades, L. (2001). Reciprocation of perceived organizational support. Journal of Applied Psychology, 86(1), 42-51. doi:10.1037//0021-901086.1.42

[12] Ismail, A., Mohamad, M. H., Mohamed, H. A., Rafiuddin, N. M., \& Zhen, K. W. (2010). Transformational and transactional leadership styles as predictors of individual outcomes. Theoretical and Applied Economics, 17(6), 89-104. Retrieved from www.researchgate.net

[13] Johari, J., Mit, D. A. C., \& Yahya, K. K. (2009). Construct validation of the Job Characteristics Scale in the Malaysian public service setting. International Review of Business Research Papers, 5(3), 58-71. Retrieved from www.bracu.ac.bd

[14] Kiesewetter, J., \& Fischer, M. R. (2015). The teamwork assessment scale: A novel instrument to assess quality of undergraduate medical students' teamwork using the example of simulation-based ward-rounds. German Medical Association, 32(2), 1-18. doi: 10.3205/zma000961

[15] Macdonald, S. (1997). The generic job satisfaction scale: Scale development and its correlates. Employee Assistance Quarterly, 13(2), 1-15. Retrieved from www.pdfs.semanticscholar.org

[16] Matin, H, Z., Jandaghi, G., \& Ahmadi, F. (2010). A comprehensive model for identifying factors impacting on development of organizational citizenship behavior. African Journal of Business Management 4(10), 1932-1945. Retrieved from http://www.academicjournals.org/ajbm

[17] Meyer, J. P., Allen, N. J., \& Smith, C. A. (1993). Commitment to organizations and occupations: Extension and test of a threecomponent conceptualization. Journal of Applied Psychology, 78, 538-551. Retrieved from www.psycnet.apa.org

[18] Nohe, C., \& Hertel, G. (2017). Transformational leadership and organizational citizenship behavior. A meta-analytic test of underlying mechanisms. Frontiers in Psychology, 8(1364), 1-3. doi: 10.3389/fpsyg.2017.01364

[19] Organ, D. W. (1997). Organizational citizenship behavior: It's clean-up time. Human Performance, 10(2), 85-97. Retrieved from www.tandfonline.com

[20] Organ, D. W., \& Konovsky, M. (1989). Cognitive versus affective determinants of organizational citizenship behavior. Journal of Applied Psychology, 74(1), 157-164. Retrieved from www.jstor.org

[21] Petrella, V. M. (2013). The effects of trust on organizational citizenship behavior: Meta-analysis. Online Theses and Dissertations, $199 . \quad$ Retrieved from http://encompass.eku.edu/etd/199

[22] Podsakoff, M. P., Mackenzie, S. B., Moorman, R. H., \& Fitter, R. (1990). Transformational leader behaviours and their followers' trust in leader, satisfaction and OCB. Leadership Quarterly, 1(2), 107-142. Retrieved from www.academia.edu

[23] Podsakoff, M. P., MacKenzie, S. B., Paine, J. B., \& Bachrach, D. G. (2000). Organizational citizenship behaviors: A critical review of the theoretical and empirical literature and suggestions for future research. Journal of Management, 26(3), 513-563. Retrieved from www.journal.sagepub.com

[24] Schwarzer, R., \& Jerusalem, M. (1995). Generalized self-efficacy scale. In J. Weinman, S. Wright, \& M. Johnston. Measures in health psychology: A user's portfolio. Causal and control beliefs, 35-37. UK: Windsor, Nfer-Nelson. Retrieved from http://userpage.fu-berlin.de

[25] Smith, C. A., Organ, D. W., \& Near, J. P. (1983). Organizational citizenship behavior: Its nature and antecedents. Journal of Applied Psychology, 68(4), 653-666. Retrieved from www.psycnet.apa.org

[26] Vigoda-Gadot, E., Beeri, I., Birman-Shemesh, T., \& Somech, A. (2007). Group-level organizational citizenship behavior in the education system: A scale reconstruction and validation. Educational Administration Quarterly, 43(4), 462-493. Retrieved from www.https://journal.sagepub.com

[27] Yoon, J., \& Lim, J. (1999). Organizational support in the workplace: The case of Korean hospital employees. Human Relations, 52(7), 923-945. Retrieved from www.sagepub.com

[28] Yulk, G. (2010). Leadership in organizations. New Jersey, NJ: Pearson Education Inc. Retrieved from www.scrip.org 